\title{
REDEFINISI LAPISAN PEMANGKU KEPENTINGAN MEDIA
}

\author{
Anna Agustina \\ Pengajar, Fakultas Ilmu Komunikasi, Universitas Pancasila \\ Email: annaagustina@univpancasila.ac.id
}

\begin{abstract}
Abstrak
Media dipercaya memiliki kekuatan untuk memengaruhi, baik individu maupun masyarakat. Kekuatan media dimulai sejak tehnologi komunikasi ditemukan. Keajegan dampak media terbukti pada praktek penggunaan media di masa PD 2, dan pada hasil kajian-kajian akademik. Di abad 20, terjadi perkembangan tehnologi komunikasi yang mengukuhkan kekuatan media. Dalam praktek dan kajian akademik hal ini banyak disajikan, namun dibalik kekuatan media perhatian pada pemangku kepentingan yang lebih beragam dari hulu ke hilir dalam industri media masih kurang. Kajian ini bertujuan untuk memaparkan para pemangku kepentingan dari hulu ke hilir dalam industri media di Indonesia. Hasil kajian ini fokus pada beberapa topik yaitu pada industri hulu media yaitu pemilik, pada produsen, dan pada bagian hilir atau distributor. Hasil kajian menunjukkan bahwa kekuatan media di Indonesia terkait pada pemangku kepentingan yang ada dari hulu ke hilir, bukan saja pada kekuatan produsen yang identik dengan redaksi dengan sumber daya yang profesional. Pemilik media yang dahulu identik dengan pemegang saham tertinggi, kini berkembang dalam berbagai skenario seperti pemilik dengan saham terbesar, pemilik ijin, atau partner. Paparan naratif dalam kajian ini menjelaskan bahwa perkembangan itu menimbulkan lapisan-lapisan baru dalam media baik horizontal maupun vertikal. Hal ini mendorong pentingnya kajian lebih lanjut yaitu pada pengertian media atau organisasi media.
\end{abstract}

Kata kunci: media, pemangku kepentingan, redefinisi media.

\section{REDEFINISI LAPISAN PEMANGKU KEPENTINGAN MEDIA}

\author{
Anna Agustina \\ Email: annaagustina@univpancasila.ac.id
}

\section{Pendahuluan}

Kekuatan media telah lama diakui memiliki pengaruh pada individu, kelompok, ataupun masyarakat dalam membentuk sikap, perilaku, ide dan persepsi terkait realitas sosial (McQuail, 2010). McQuail lebih dalam lagi menggambarkan bahwa dalam kehidupan populer ataupun lingkungan akademik, kekuatan media diakui keajegannya dalam berbagai situasi. Baik dalam situasi masyarakat dianggap pasif dalam menerima informasi dari media, seperti 
pada konteks Perang Dunia 2 dimana pemilik media terbatas pada penguasa, maupun dalam situasi masyarakat memiliki kekuasaan untuk menentukan apa yang akan dikonsumsi dari media. Nada yang hampir serupa juga disampaikan oleh Murdock (1998):

"the mass media are therefore, simultaneously, both a key resource for the everyday construction of meaning and a significant constraint on the range and direction of such construction".

Pendapat Murdock ini sejalan dengan Blumer dan Gurevitch (1982) yang menggambarkan bahwa media memiliki dampak positif dan negatif atau memberikan keuntungan dan kerugian bagi para kelompok yang memiliki kepentingan atau kelompok yang ada di masyarakat, seperti: orang tua, institusi, agensi periklanan, politisi dan advokat. Mengutip hasil kajiannya yang menekankan bahwa media memiliki efek yang signifikan pada audiensnya, Blumer dan Gurevitch (1982) menyatakan:

"Underlying all these reactions is a common assumption: that the mass media do indeed have considerable influence over their audiences; that in this sense they are powerful".

Selain berfungsi sebagai sumber dari terbentuknya sikap, perilaku, ide, dan persepsi tentang realitas sosial (McQuail, 2010), media sebagai pusat kehidupan modern juga berfungsi sebagai distributor dan pembuat paket berita, serta pembentuk dan penguat moralitas individu maupun masyarakat (Schudson, 1995; hal. 21). Schudson menjelaskan bahwa media bukan hanya mekanisme sosial yang memberikan tempat bagi masyarakat untuk memiliki pengalaman tentang dunia, tetapi media juga merupakan institusi/organisasi penting dan utama bagi masyarakat modern dalam membangun makna tentang fenomena yang ada di sekelilingnya.

Memahami fakta tentang banyaknya kajian terdahulu yang membahas kekuatan media yang dalam berbagai bentuk memengaruhi individu dan masyarakat, serta fakta tentang media menjadi hal yang dicari oleh individu dan masyarakat modern untuk mendapatkan pengetahuan, pengakuan diri serta untuk konfirmasi atas keyakinan yang dimiliki, maka 
makalah ini melihat masih sedikitnya kajian yang membahas pemangku kepentingan yang ada dibalik media yang telah diakui kekuatannya itu. Padahal mereka yang ada di balik media inilah yang menentukan informasi apa yang boleh dan tidak boleh disajikan di media. Pemangku kepentingan inilah yang besar pengaruhnya dalam membangun makna tentang realitas sosial dalam diri individu dan masyarakat. Lansekap media di Indonesia yang berubah sangat pesat sejak 1998 menjadi konteks pentingnya sensitifitas individu dan masyarakat tentang para pemangku kepentingan yang eksis dibalik media-media yang ada di Indonesia. Fokus atau batasan kajian ini adalah pada identifikasi para pemangku kepentingan yang ada di balik media di Indonesia. Memahami siapa saja pemangku kepentingan dalam institusi media menjadi penting karena kajian ini berangkat dari asumsi bahwa memahami siapa pemangku kepentingan dalam media dapat mendorong munculnya sensitifitas individu dan masyarakat dalam memutuskan pilihan media untuk dikonsumsi. Tujuan kajian ini adalah untuk menggambarkan para pemangku kepentingan media dalam lansekap kepemilikan media di Indonesia yang mengarah pada sistim oligopoly. Harapan dari kajian ini adalah dapat memicu pemikiran kritis bagi individu, masyarakat, serta akademisi dalam memilih, memutuskan menggunakan media, mendefinisikan media serta mengkaji kepemilikan media.

\section{Tinjauan Pustaka}

Sejak pertama kali Indonesia memiliki organisasi media kelompok dominan yang mengelola media beragam dari para pejuang kemerdekaan, masyarakat, pemerintah, hingga pengusaha. Dominasi pihak yang mengelola kemudian membentuk lansekap media dan tercermin dalam sistim komunikasi Indonesia yang berlaku pada masanya masing-masing. Untuk memahami para pemangku kepentingan yang ada di Indonesia, maka perkembangan media di Indonesia serta pengelola yang mendominasi media menjadi penting. Dengan referensi yang dituliskan antara lain oleh Wiratraman (2014), Kakiailatu (2007), Junaenah, dkk. (2015), Nugroho, dkk. 
(2012a, 2012b), dan Lim (2011), maka disusun urutan perkembangan media terkait dengan para pemangku kepentingannya seperti yang tercantum pada paragraph-paragraf berikut ini.

Media di Indonesia mulai muncul sejak VOC mengimplementasikan freedom of the press di Indonesia. Organisasi media pertama ini dimiliki oleh pengusaha yang menjajah Indonesia yaitu VOC. Bentuknya adalah koran cetak, dengan konsep media berita, dan berbahasa Belanda. Kontennya terkait kabar yang terjadi di Indonesia serta kegiatan VOC yang terjadi di Indonesia. Publiknya jelas para orang Belanda yang tinggal di Indonesia maupun yang tinggal di Belanda. Susunan dalam redaksi hampir seluruhnya adalah orang Belanda. Beberapa orang Indonesia yang bersekolah di organisasi pendidikan Belanda diberikan kesempatan untuk menjadi bagian dari jajaran anggota redaksi. Dari gambaran media ini terlihat bahwa para pemangku kepentingan dalam media adalah pengusaha yang berada di bawah naungan perusahan VOC. Media dijadikan alat untuk VOC dalam menyampaikan informasi yang ada di Indonesia kepada publiknya, baik yang ada di Indonesia maupun yang ada di Belanda. Kepentingan VOC mendominasi isi yang ditampilkan oleh media.

Beberapa orang Indonesia yang diberi kesempatan untuk menjadi anggota redaksi dalam media Belanda ini, beberapa tahun kemudian diberi kesempatan untuk mengelola media berbahasa Indonesia. Kajian terdahulu tidak dengan rinci memaparkan kepemilikan media untuk mengetahui siapa para pemangku kepentingan di dalamnya. Tetapi tujuan dari media berbahasa Indonesia ini ditetapkan oleh pemerintah yaitu untuk memperkenalkan berbagai hal baru bagi orang Indonesia agar dapat melakukan pekerjaannya dengan baik sehingga menguntungkan pemerintah yang berkuasa di Indonesia atau VOC di hadapan pemerintah dan masyarakat Belanda. Ketidakpatuhan menyajikan konten media yang ditujukan untuk memenuhi visi organisasi mengakibatkan beberapa pengelola media divonis bersalah karena 
tidak menjalankan misi dan visi media. Hukuman ini membuat kalangan terdidik Indonesia yang terlibat dalam pengelolaan media pertama berbahasa Indonesia ini makin bersemangat untuk membuat tulisan tentang pentingnya bernegara dan memiliki pemerintahan yang lepas dari VOC dan menyebarkannya ke seluruh Indonesia. Media yang digunakan adalah media cetak, dikelola oleh kalangan pejuang Indonesia dengan biaya pengelolaan yang tidak dirinci dalam kajian terdahulu. Pemangku kepentingan utama dalam masa ini disebutkan dalam kajian terdahulu adalah mereka yang terdidik di Indonesia yang memiliki kesadaran bahwa kebebasan bernegara itu penting, dan memiliki ketertarikan untuk menciptakan pemerintahan sendiri.

Pada masa awal kemerdekaan, ketika Sukarno menjadi presiden pertama Indonesia, pemerintah memiliki memberikan kebebasan berekspresi yang seluas-luasnya kepada seluruh rakyat Indonesia, termasuk pada kebebasan pers. Banyak media muncul di Indonesia dengan berbagai bahasa dan berbagai konten. Para pemangku kepentingan media ketika itu beragam, mulai dari para pejuang kemerdekaan seperti Pramoedya Ananta Toer, juga para pengusaha dan para pemilik partai. Namun sebagian besar dimiliki oleh partai. Banyaknya partai yang muncul di awal kemerdekaan mendorong mereka untuk memiliki media dengan konten berita terkait dengan visi dan misi partai. Namun, setelah beberapa tahun setelah kemerdekaan, pemerintah menyadari bahwa kekuatan media dapat mengancam keberadaan pemerintah yang berkuasa pada masa itu sehingga pemerintah mulai mengatur seluruh kegiatan organisasiorganisasi media.

Kesadaran pemerintahan Indonesia yang pertama ini kemudian mendorong pemerintah untuk mengatur bukan saja kegiatan organisasi media, tetapi juga masuk hingga isi media. Hal ini mendapat reaksi keras dari para pemilik media. Menghadapi hal ini pemerintahan Sukarno 
kemudian melakukan beberapa tindakan seperti pembredelan, dan pembuangan pemimpin redaksi ke daerah terpencil, seperti yang sebelumnya dilakukan oleh pemerintah/VOC. Peran pemerintah kembali dominan.

Pada masa Orde Baru, pemerintah juga dominan mengatur media bukan saja pada perkembangan organisasi media di Indonesia tetapi juga pada konten yang idealnya menjadi kebijakan dalam redaksi media. Hampir seluruh media yang beroperasi di Indonesia dimiliki oleh pemerintah. Pemilik media diatur dan dibatasi oleh pemerintah. Seluruh organisasi media harus mengikuti visi dan misi pemerintah yang berkuasa. Hal ini juga terjadi di beberapa Negara maju seperti di Amerika dan di Swedia. Namun ketika media dijadikan alat propaganda partai yang berkuasa, organisasi media di Amerika dan Swedia menolak. Mereka tetap menjalankan fungsi media sebagai watch-dog terhadap pemerintah dengan perlindungan perundangan kebebasan pers dan kebebasan individu. Disini bedanya dengan media yang berada di Indonesia. Pada masa Orde baru, media tidak memiliki perlindungan hukum untuk menjalankan fungsinya menjadi watch-dog. Semua media dipaksa untuk menjadi lap-dog nya pemerintah. Kondisi ini kemudian mendorong para jurnalis untuk bergerilya dalam menjalankan fungsinya sebagai watch-dog. Seluruh organisasi media yang takut untuk dibredel oleh pemerintah lalu bermain aman dalam menyajikan berita. Namu, Masih ada beberapa media yang konsisten menyajikan berita yang kritis terhadap pemerintah, dan banyak jurnalis yang bergerilya menyelipkan unsur kritik pada pemerintah melalui beritaberita yang ditulisnya.

Hal yang menjadi unik pada pemerintahan orde baru ini adalah dibentuknya Dewan Pers dan Komisi Penyiaran Indonesia (KPI) yang memiliki pekerjaan memonitor seluruh isi media di Indonesia dengan salah satu tugasnya adalah memfasilitasi konflik yang terjadi antara berita di media dan mereka yang diberitakan. Pembentukan kedua dewan ini memiliki latar 
belakang adanya tekanan internasional untuk mengakomodasi kebebasan pers, sehingga pemerintah menjalankan dualisme pengawasan pada media: dilakukan oleh pemerintah melalui Departemen penerangan dan dilakukan oleh Dewan Pers atau KPI yang dibentuk dari unsur masyarakat, akademia dan profesi.

Pada awal masa pasca orde baru, organisasi media di Indonesia mengalami kebebasan pers yang sangat tinggi kembali seperti di awal kemerdekaan. Pemerintahan Habibie menutup organisasi pemerintah yang memiliki tugas untuk memonitor media di Indonesia. Hal ini mendapat respon sangat baik bukan saja dari para pemilik media dan jurnalis tetapi juga dari pengusaha dan dunia internasional. Pemerintah menyerahkan mekanisme pengawasan media kepada profesi yang terlibat didalamnya termasuk kepada Dewan Pers dan KPI.

Kebebasan pers ini juga diikuti dengan kebebasan memiliki media, sehingga pada pasca orde baru banyak organisasi media baru bermunculan. Lim (2010) menggambarkan ada lebih dari 2000 lisensi media yang dikeluarkan oleh pemerintah. Para pemilik media bukan saja mereka yang memiliki visi untuk menjalankan fungsi pers sebagai watch-dog tetapi juga para pengusaha yang memiliki visi bisnis. Mekanisme kepemilikan media diatur dengan tata kelola bisnis sehingga banyak bisnisman yang tertarik untuk membuat media. Hal inilah yang kemudian mewarnai lansekap media di Indonesia. Para pengusaha memiliki media dan mereka menjadikan media yang dimilikinya sebagai alat untuk menunjang visi-misi bisnisnya.

Kemajuan tehnologi komunikasi kemudian mendorong para pengusaha pemilik media ini untuk mengambangkan medianya dalam berbagai strategi bisnis yang dimungkinkan terjadi. Mulai dari memecah kepemilikan dalam skenario jumlah saham, partner usaha, hingga pada 
skenario franchise. Media yang memiliki cakupan nasional dalam lisensinya kemudian berusaha untuk bekerjasama dengan media lokal. Bahkan berusaha mengakuisisi media lokal sebagai cabang dari media nasional, atau media nasional membeli sebagian saham media lokal dengan perjanjian yang mereka sepakati misalnya sesuai dengan tata kelola dalam skenario usaha franchise.

\section{Metodologi}

Metodologi pengumpulan data dilakukan dengan wawancara terstruktur tentang pengelolaan media, pemangku kepentingan, dan kebijakan media. Wawancara pada 10 profesional yang telah memiliki pengalaman sebagai jurnalis telah dilakukan langsung di daerah dimana informan tinggal. Seluruh informan pada saat diwawancara bukan saja masih menjalankan proses jurnalistik yang menandakan mereka masih melakukan profesinya, tetapi juga telah memiliki jabatan managerial di organisasi media dimana ia bekerja lebih dari 10 tahun. Ke 10 informan adalah mereka yang memiliki wewenang dalam membuat kebijakan dalam memutuskan informasi yang boleh atau tidak boleh disajikan di media sesuai dengan kebijakan redaksi dan kebijakan organisasi media.

\section{Hasil Analisis dan Diskusi}

Hasil dan analisis akan memaparkan data yang didasarkan pada kajian pustaka. Peran pemerintah selalu dominan di masa penjajahan, orde lama dan orde baru diamini oleh semua informan. Lebih rinci lagi para informan menjelaskan bahwa dominasi pemerintah sangat berkurang pada 2 masa ketika perpindahan pemerintahan terjadi pada masa dari pemerintah kolonial ke Masa pemerintahan awal orde lama dan dari masa orde baru ke masa awal pemerintahan pasca orde baru. Setelah beberapa tahun pemerintahan orde lama dan pasca 
orde baru berkiprah, Indonesia kembali didominasi oleh kelompok kepentingan pemerintah di masa orde lama dan pengusaha di masa pasca orde baru.

Ketika pemerintah mendominasi media, terjadi beberapa kali peristiwa yang melanggar kebebasan pers dan individu seperti pembredelan dan penutupan media dengan membuang pemimpin redaksi ke daerah terpencil atau dalam beberapa kasus memenjarakan jurnalis atau pemilik media dan membunuh jurnalis. Informan di Jakarta dan Aceh menceritakan bahwa pemerintah Belanda pernah memenjarakan beberapa pemilik media yang melanggar arahan VOC. Informan lain di Aceh dan di Pontianak menjelaskan pernah terjadi pembunuhan pada jurnalis yang dianggap mengancam pemerintah pada masa orde baru. Pemilik media yang juga pejuang kemerdekaan, dan mereka yang berjuang untuk menjalankan fungsi media sebagai watchdog menjadi sasaran pemerintah dalam memberikan hukuman.

Variasi pemangku kepentingan pada masa colonial, orde lama dan orde baru dapat diidentifikasi sebagai berikut:

a. pada masa kolonial

Pemilik media adalah VOC yang juga pemerintah yang berkuasa pada masa itu. Para pengelola media atau tim redaksi adalah karyawan VOC yang mengikuti seluruh arahan dari pemilik dalam memproduksi konten media, dengan tujuan menjalankan visi misi organisasi VOC. Publik media terbatas pada mereka yang berbahasa belanda dan pemerintah Belanda.

Pada organisasi media Indonesia pertama di masa kolonial terlihat pemangku kepentingan mulai bervariasi: sistim komunikasi di Belanda yang mewajibkan seluruh warganya untuk mendukung kebebasan pers memaksa VOC yang ada di Indonesia untuk memberikan kesempatan pada munculnya media berbahasa Indonesia yang diminta oleh kalangan terdidik 
Indonesia. Pemiliknya adalah kalangan terkemuka Indonesia yang pernah mengikuti pendidikan Belanda, memiliki pengetahuan bahwa Negara berdaulat itu penting, dan juga pengusaha Indonesia. Persetujuan pemerintah Belanda mendirikan media berbahasa Indonesia muncul karena terjadi kesepakatan bahwa media yang terbit ini memiliki visi memperkenalkan alat-alat baru dan modern serta mendidik masyarakat Indonesia untuk bisa menunjang tujuan VOC. Namun pada perjalanannya hal ini berkembang menjadi media untuk memberikan wawasan dan pendidikan politik pada masyarakat Indonesia yang kemudian dianggap mengncam pemerintah Belanda. Menurut informan yang sudah snagat senior di Jakarta, media tersebut kemudian ditutup oleh Belanda, namun para penulis dan jurnalis yang terbiasa mengisi media tetap menulis dan menyebarkannya dalam media cetak terbatas ke seluruh Indonesia. Media dijadikan alat pemersatu bangsa. Pemangku kepentingan bisa diidentifikasi pemberi lisensi, pemilik media, pengelola media yang pada masa ini adalah redaksi, dan penulis.

b. pada masa orde lama

Pemangku kepentingan media pada masa orde lama adalah kelompok-kelompok yang memiliki kepentingan yang beragam dan pemerintah. Kelompok-kelompok kepentingan ini bervariasi dari kelompok partai, pengusaha, ras, maupun kelompok keagamaan, Pemilik media pada masa orde lama adalah mereka yang juga menjadi tim redaksi atau pengelola media. Distributor media adalah dari kalangan kelompok yang sama, jejaring mereka sendiri. Dari hulu ke hilir adalah kelompok yang sama dan media yang diperbolehkan hanya media cetak. Media radio hanya dimiliki oleh pemerintah. Peran pemerintah dominan dalam mengawasi isi media. Sistim komunikasi Indonesia dipimpin oleh presiden dengan visi mendorong pengakuan pihak internasional tentang kedaulatan Indonesia dan mendorong visi 
presiden. Hal ini menjadikan presiden sebagai salah satu pemangku kepentingan selain pemerintah dan kelompok-kelompok kepentingan yang memiliki media.

c. pada masa orde baru

Para informan menggambarkan pemangku kepentingan pada masa orde baru adalah semu, karena pada dasarnya sama dengan orde lama yaitu hanya pemerintah yang berkuasa. Tetapi keberadaan media dan kebebasan pers di Negara yang sudah berdaulat Indonesia mejadi salah satu sorotan dunia internasional. Pengelolaan media mulai dari pemberian ijin, pemilik media, penetapan pemimpin redaksi, hingga konten media diatur, diberikan ijin dan diawasi oleh pemerintah. Tuntutan dari level internasional terkait kebebasan pers diakomodasi dengan didirikannya asosiasi profesi PWI dengan bagian pengawasan isi media di dalamnya, membentuk dewan pers, dan KPI untuk mengawasi isi sesuai karakter media masing-masing. Namun semua organ ini beroperasi di bawah kendali pemerintah. Pemangku kepentingan lain selain pemerintah -pemilik media, pengelola media dan Tim redaksi, dewan pers KIP, PWIharus mengikuti arahan pemerintah. Jenis media lebih banyak -radio, tv, Koran, majalah, tabloid- dan pengelolaannya melibatkan pihak swasta namun jumlah media dibatasi, dan pemilik media ditentukan oleh pemerintah. Pemilik media masa orde baru didominasi oleh para anggota partai yang sama dengan partai yang berkuasa.

\section{d. masa Pasca orde baru}

Pemangku kepentingan media di masa pasca orde baru awalnya masih sama dengan masa orde baru dengan kebebasan pers yang lebih tinggi. Media dapat memberikan kritik terbuka pada pemerintah. Setelah pemerintah menutup Departemen Penerangan, maka pemerintah menyerahkan pengawasan pada pers dan para professional di bidang itu sendiri. Pers diminta untuk bisa memonitor dirinya sendiri. Konten media pada masa ini menjadi sangat bebas, 
sehingga terjadi peristiwa yang membawa pers ke meja hijau. Hal ini menambah pemangku kepentingan media bukan saja pemerintah, pemilik media, pengelola media dan publiknya tetapi juga polisi, pengacara, dan nara sumber berita. Nara sumber berita dapat mengajukan media atau jurnalis ke pengadilan berdasarkan hukum positif pidana maupun perdata.

Pada pasca orde baru ini, peningkatan pemangku kepentingan juga terjadi bukan saja pada sisi pemilik media, tetapi juga pada produsen konten, dan pada distributor konten. Berkembangnya tehnologi telekomunikasi memungkinkan beragam jenis usaha untuk bergabung dalam industri media. Dari sisi pemilik media yang lama, mereka mengembangkan usaha ke bidang-bidang lain selain usaha media, seperti hotel, perkebunan, industri berat, dan sebagainya. Media yang awalnya hanya media cetak, kemudian berkembang menjadi media online TV, radio, streaming dan media sosial. Tehnologi digital memungkinkan pemilik media mengembangkan organisasi medianya sekaligus ke semua jenis media massa. Fenomena konvergensi media memungkinkan pemilik media bukan saja pengusaha yang tertarik sebagai penyedia berita, tetapi juga pengusaha penyedia barang elektronik, dan perusahaan penyedia saluran telepon dan seluler, serta kelompok kepentingan yang paham atas kekuatan media dapat menguntungkan bisnis dan kepentingannya yang lain. Di Indonesia para pemilik media kemudian menjalin kerjasama dengan pihak-pihak tersebut sehingga media sarat dengan kepentingan bisnis pihak yang bekerjasama. Informan di Makassar memberikan contoh misalnya SCTV dengan Singtel, Indosat dengan Indovision atau Samsung dengan berbagai media elektroniknya dengan provider telepon seluler. Skenario kepemilikan ini juga bisa dilihat dari terpusatnya kepemilikan media di Indonesia pada hanya 5 pemilik media bagi sekitar 3 juta penduduk Indonesia. 
Pada tahap produksi, di pasca orde baru ini para produser informasi/pesan yang ditayangkan media juga berkembang pemangku kepentingannya seiring dengan berkembangnya konten media yang bukan saja memberikan informasi, tetapi juga menghibur dan mendidik. Produser konten berita di media oleh beberapa informan disebutkan: selain redaksi, ada juga penyedia konten seperti Antara, Berita Satu, dan CNN Indonesia untuk berita. Tambahan yang ada dalam redaksi saat ini adalah tim teknik dalam redaksi yang saat ini fungsinya sangat vital karena berita harus dapat diakses bukan saja di media mainstream tetapi juga di media sosial yang dapat diakses dari berbagai media telekomunikasi dengan karakter masing-masing media yang berbeda seperti handphone, TV, radio, online, atau gadget lainnya. Banyaknya pemangku kepentingan dalam kepemilikan media mendorong berbagai akun untuk meminta persetujuan pengguna dalam mengakses berbagai produk. Namun menurut semua informan, pengguna sudah tidak membaca syarat dan ketentuan yang disajikan pemilik ketika akan mengambil informasi/pesan yang diperlukan. Pengguna cenderung untuk langsung meng-klik ya saya setuju agar informasi yang dibutuhkan segera dapat diakses dan digunakan.

Sementara untuk hiburan selain tim produksi dalam media masing-masing ada banyak production house yang memproduksi bermacam konten terkait program acara yang ditujukan untuk mendidik ataupun untuk menghibur seperti sinetron, talk show, produser film, pencipta lagu, atau penyedia iklan. Beragam media dapat diakses dari berbagai tempat memungkinkan media mengunduh program dari media sosial yang kemudian dijadikan program acara media mereka. Produksi program acara tidak lagi harus dilakukan dari nol. Banyak pihak media yang melakukan reproduksi program acara dibandingkan produksi dari peristiwa yang sebenarnya. Terutama untuk program hiburan. Mekanisme membeli program sudah jadi dari berbagai pihak menjadi lazim. Budaya menjadi broker menjadi berkembang di media. Para 
broker acara menjadi salah satu pemangku kepentingan yang jarang sekali diperhatikan, namun tumbuh subur.

Sumber program ini menjadi pemangku kepentingan media seperti youtube atau mesin pencari program seperti google juga termasuk. Pembuat aplikasi yang memudahkan pengguna atau masyarakat untuk akses informasi juga menjadi pemangku kepentingan berbagai informasi. Orang-orang yang paham tehnologi informasi, paham memproduksi pesan, memiliki jejaring dan akses serta memiliki modal menjadi pemangku kepentingan dalam klaster produser.

Distributor konten media kini juga beragam, bukan saja stasiun tv atau radio atau media cetak saja, tetapi perkembangan telekomunikasi juga menambah media distribusi konten lebih beragam yaitu melalui media streaming, online, atau media sosial. Pemilik masing-masing media distribusi ini juga menjadi pemangku kepentingan media pada masa ini. Interaksi yang dimungkinkan terjadi tanpa bertatap muka antara pengguna dan distributor dalam distribusi produk baik berita maupun informasi umum kemudian menjadi hal yang biasa dan mengaburkan siapa sebenarnya pemangku kepentingan yang dominan.

\section{Kesimpulan}

Banyaknya pihak yang terlibat dalam kepemilikian, produksi dan distribusi pesan melalui media membuat pengguna tidak lagi berpikir siapa pemangku kepentingannya. Pemangku kepentingan media saat ini sudah menjadi hal yang take for granted bagi pengguna media. Pengguna media tidak lagi mau membaca syarat dan ketentuan yang berlaku ketika akan membuka akun untuk dapat mengakses informasi yang diinginkan/diperlukan. Kecenderungan yang terjadi adalah langsung menerima atau setuju dengan apapun yang 
dituliskan oleh produk yang akan digunakan/diambil informasinya. Banyak akun dibuat oleh seorang individu. Dan pemangku kepentingannya bukan hanya pemerintah, tetapi banyak pengusaha dan tim IT yang sudah tentu mereka tidak mau rugi dengan apa yang telah mereka berikan ke publik atau ke pengusaha yang membeli jasa dan produk mereka. Pemilik modal terbesar media, para pemegang saham media, pemegang lisensi acara dalam media, produser acara, jurnalis, bintang film atau presenter acara, pemilik media sosial dimana program acara didistribusikan, pengiklan, pemilik frekuensi penyedia saluran atau penyedia Wi-fi, produsen gadget adalah beberapa pemangku kepentingan media yang mencari untung dari penggunaan media yang kita lakukan. Lapisan pemangku kepentingan media tidak lagi mudah untuk dideteksi seperti pada masa sebelumnya. Kecenderungan menunjuk pemilik saham mayoritas sebagai pemilik memang sulit untuk dihindari. Namun pemahaman adanya lapisan pemangku kepentingan lain ketika kita memilih akan mengakses pertandingan bola siaran tunda di youtube atau di media online si pemilik lisensi siaran di Indonesia perlu dimunculkan. Kecenderungan pengguna untuk mencari pelayanan yang terbaik biasanya menjadi dasar keputusan pengguna. Dan hal ini menjadi dasar keputusan seluruh manusia. Namun bila bisa memilih dengan kualitas yang sama, kesadaran menggunakan media dengan pemahaman lapisan pemangku kepentingan ini diharapkan dapat memengaruhi keputusan penggunaan media.

Penelitian berikutnya akan sangat menarik bila mengkaji lapisan pemangku kepentingan ini dari hulu ke hilir atau dari kepemilikan media dengan skenario kepemilikan yang dilakukan oleh media, dominasi produsen konten yang digunakan dalam media berasal dari mana, dalam bentuk tayangan apa dengan siapa pemilik lisensinya, serta didistribusikan melalui media apa saja hingga kecenderungan orang Indonesia menggunakan media apa untuk akses informasi apa. Keterbukaan informasi publik dimungkinkan untuk mendapatkan informasi ini, namun 
akses dan keterbukaan informasi yang terkait dengan hukum diasumsikan akan menjadi halangan untuk mendapatkan informasi yang lengkap. Informasi tentang pemilik media sosial yang banyak digunakan oleh orang Indonesia dan bagaimana pengaturan penggunaan saluran frekuensi Indonesia ketika mengakses media sosial tersebut belum popular juga dalam kajian ilmiah. Apakah diatur pemerintah, apakah langsung ada kontrak antara penyedia saluran frekuensi dengan youtube atau instagram misalnya? Masih perlu digali lebih lanjut.

\section{Daftar Pustaka}

Schudson, M. e. a. (2009). Objectivity, Professionalism and Truth seeking in journalism. In K. Wahl-Jorgensen \& T. Hanitzcsh (Eds.), The Handbook of Journalism Studies. New York: Routledge.

Wirataman, H. P. (2014). Press freedom, law and politics in Indonesia: a socio-legal study. from Leiden University http://hdl.handle.net/1887/30106

Junaenah, I. (2015). Indonesia Democracy Index (IDI): the effort to encourage democratic provincial government. International Journal of Social Science and Humanity, 5(5), 466-471.

Lim, M. (2011). @ crossroads: Democratiozation \& corporatization of media in Indonesia. Retrieved from

Dispensa, J. M., \& Brulle, R. J. (2003). Media's social construction of environmental issues: Focus on global warming - a comparative study. The International Journal of Sociology and social Policy, 23(10).

Fiske, e. a. (2006). Universal dimensions of social cognition: warmth and competence. Trends in Cognitive Science, 11(2), 77-83.

Entman, R. M. (2007). Framing bias: media in the distribution of power. Journal of Communication, 57, 163-173. doi:doi:10.1111/j.1460-2466.2006.00336.x

Kakiailatu, T. (2007). Media in Indonesia: Forum for political change and critical assessment. Asia Pacific Viewpoint, 48(1), 60-71.

Lockwood, A. (2010). Seeding doubt: how sceptics have used new media to delay action on climate change. GHIR, 2.

Chock, T. M. (2011). Is it seeing or believing? exposure, perceived realism, and emerging adults' perceptions of their own and others' attitudes about relationships. Media Psychology, 14, 355-386.

Lim, M. (2011). @ crossroads: Democratiozation \& corporatization of media in Indonesia. Retrieved from

Nugroho, Y. e. a. (2012). Mapping the landscape of the media industry in contemporary Indonesia. Retrieved from

Nugroho, Y. e. a. (2012). Media and the vulnerable in Indonesia: Accounts from the margins. Retrieved from

Schafer, e. a. (2014). What drives media attention for climate change? Explaining issues attention in Australian, German and Indian print media from 1996 to 2010. The International Communication Gazette, 76(2), 152-176. 
Wirataman, H. P. (2014). Press freedom, law and politics in Indonesia: a socio-legal study. from Leiden University http://hdl.handle.net/1887/30106

Junaenah, I. (2015). Indonesia Democracy Index (IDI): the effort to encourage democratic provincial government. International Journal of Social Science and Humanity, 5(5), 466-471.

\section{Tentang Penulis}

Anna Agustina memiliki latar belakang pendidikan komunikasi sejak mengambil perkuliahan jenjang sarjana dan master di UI. Jenjang kedoktorannya diambil di Universiti Sains Malaysia, dengan kajian komunikasi lingkungan di Indonesia. Profesi sebagai dosen Ilmu Komunikasi di Universitas Pancasila dilakukan sejak ia dipercaya oleh beberapa ahli komunikasi dari UI dan Rektor Universitas Pancasila untuk mendirikan Fakultas Komunikasi di Universitas Pancasila dalam tim pendirian FIKOM tahun 2007 hingga kini (2018). Beberapa kajian yang dilakukan dan pernah diterbitkan dalam buku yang dikeluarkan oleh ASPIKOM adalah tentang komunikasi dan lingkungan. Sebelumnya, Anna adalah konsultan komunikasi yang ahli dalam bidang pelatihan dan peningkatan kapasitas, outreach, dan penyusun program strategi komunikasi bagi sebuah program/proyek. 